\title{
Charles Csuri, a számítógépes képzőmüvészet úttörője és teoretikusa
}

\section{TISZTELETADÁS EGY ÖREG MESTERNEK.}

\section{Szerzői információ:}

\section{Z. Karvalics László}

Történész, az információs társadalom kutatója, a Szegedi Tudományegyetem Könyvtártudományi Tanszékének tanszékvezetô egyetemi docense, az ITTK (Információs Társadalom- és Trendkutató Központ) volt igazgatója, 2006-tól örökös tiszteletbeli elnöke. Számos kurzust dolgozott ki az információs társadalommal kapcsolatos ismeretek oktatásához, e tárgyban több szakkönyv és tanulmány szerzóje. A Kar Kiváló Oktatója (1999), Széchenyi-ösztöndíjas (2000-tốl). Fontosabb könyvei: Fogpiszkáló a hálózaton (2000), Az információs társadalom keresése (2002), Információ, társadalom, történelem (2003), Bevezetés az információtörténelembe (2004).

Így hivatkozzon erre a cikkre:

Z. Karvalics László. „Charles Csuri, a számítógépes képzőművészet úttörője és teoretikusa.” Információs Társadalom IX, 1. szám (2009): 7-9.

A folyóiratban közölt müvek

a Creative Commons Nevezd meg! - Ne add el! - Így add tovább! 4.0 
Z. Karvalics László

\section{Charles Cisuri, a számítógépes képzômúvészet úttörője és teoretikusa}

(Elöljáró beszéd egy Öreg Mester gondolatai elé)

„In the short history of computer art, Charles Csuri may be the nearest thing, in this new art form, to an Old Master."

(Paul Trachtman: Charles Csuri is an „Old Master” in a new medium. Smithsonian Magazine, 1995. február)

A magyar származású Charles Csuri (barátainak és „hivatalosan”, írásban és élószóban is: Chuck) a „digitális múvészet és a számítógépes animáció atyja”. ${ }^{1}$ Egybehangzó vélekedés szerint vele született meg és indult útjára 1963-64-ben a számítógépes múvészet.

Hazai (meglehetôsen gyér) recepciójáról és életútjának fontosabb állomásairól megjelent már egy magyar nyelvú összefoglaló, ${ }^{2}$ de Csuri elméleti jellegú írásaival, gondolkodói portréjával eddig legfeljebb gazdag honlapjának ${ }^{3}$ látogatói ismerkedhettek meg. A legmegfelelóbb módja Csuri „felfedezésének” - és „bevezetésének” a hazai közgondolkodásba - a Mester föld körüli úton levố, szenzációs életmúi-kiállításának időszakos Magyarországra hozatala volna, hogy valódi megismerése által sokakat inspirálhasson alkotói világának elmélyüilt elemzésére.

Csuri csillapíthatatlan kíváncsiságú, játékos, csak Szász Endréhez mérhetôen lefegyverzố könnyedségú és tehetségú múvész, aki a Forma és a Technika forradalmában a magabiztosan uralt festói mikrokozmosz kitágításának lehetőségét látta meg mindenkinél korábban. A számítógépes grafika mellett a számítógéppel generált szobroktól a kalligráfiavonalak háromdimenziós megjelenítésén át a kerámiamúvészetig szinte minden érdekli, és minden múfajjal próbálkozik, ha abban örömét leli. Az animációsfilmkészítés egyik pionírja. ${ }^{4} \mathrm{Ha}$ életmúve közismert volna, akkor számos szempontból Victor Vasarely (Vásárhelyi Gyớzó) mellett lenne a helye a panteonban. A világhírú, Pécsról indult múvész az 50-es évek végén jutott el oda, hogy a múalkotások megjelenítésének, sokszorosításának és demokratizálásának lehetôségeit a számítógépes

\footnotetext{
',Father of digital art and computer animation”. In Paul 'Trachtman: Charles Csuri is an ,Old Master” in a new medium. Smithsonian Magazine, 1995. február.

2 Z. Karvalics László: „A monitor a festôvásznam.” A számítógépes múvészet magyar úttörôjéról. In Hegyi Ádám - Simon Melinda (szerk.): „Apró cseppekböl lesz a zaipor:” Bakonyi Géza emlékkönyv. Szeged, 2008, Szegedi Egyetemi Kiadó - Juhász Gyula Felsőoktatási Kiadó, 129-136.

${ }^{3}$ A www.csuri.com nem egyszerúen „személyes honlap”, hanem egyidejúleg az életmú keresztmetszetét adó képtár és archívum, interjú- és esszégyújtemény és múvészeti blog. A legutolsó bejegyzés 2009 januárjában kelt.

“A 60-as években megkezdett kísérletekkel indult „pályaívének” lezárásaként 200)-ben Csuri társalapítója lett a világ egyik legelsô számítógépes animációs gyártó cégénck (Cranston/Csuri Productions, CCP).
} 
technikában keresse (a mindenütt jelen levố luminokinetikus képernyớk segítségével), ${ }^{5}$ és néhány év múlva megtette azt a lépést, hogy a múalkotások létrehozásához is új „médiumként” találta meg a számítógépet. Ahogy egy helyütt ${ }^{6}$ írja: mint festốt a számítógépben rejlő potenciál múvészeti felhasználása érdekelte, sokkal inkább ösztönösen, mint tudatos választás vagy felismerés eredményeként. Saját magára úgy tekint, mint a legelsố múvészre, aki számítógéppel kezdett alkotni ${ }^{7}$ (megkülönböztetve magát azoktól a technológusoktól és kutatóktól, akik számítógépes munkájuk „oldalvizén” múalkotásnak tartott „,kimeneteket”, például plotterrajzokat is gyártottak).

Szorgos történészek természetesen kimutatják, ${ }^{8}$ hogy a kezdetek még korábbiak: az iowai matematikus és múvész, Ben Laposky már 1950-ben múalkotást hoz létre úgy, hogy analóg oszcilloszkóppal elektronikusan gerjesztett fénymintázatokat vesz fel nagy sebességú filmre, megalkotva az „oszcillont”. A Boeing mérnökének, William Fetternek köszönhetjük a számítógépes grafika (computer graphics) kifejezést: ő 1960-ban, a repülőgépülések tervezéséhez hívta segítségül az emberi test számítógéppel generált képét. Az 1961-ben Bill Russel és társai által kifejlesztett Spacewar! többek szerint nem egyszerúen a legelsố számítógépes játéknak, hanem egyúttal a legkorábbi számítógépes múvészeti alkotásnak is tekinthető. Ivan Sutherland Sketchpadje, az egér őse, az ember és a számítógép közötti grafikai kapcsolatot lehetôvé tévố technológia is 1961-ben, tehát még Csuri fellépése elốtt született meg. Lehetne természetesen mondani, hogy amit Laposky csinált, az elektronikus múvészet (electronic art), de nem számítógépes múalkotás; hogy Fetter grafikáit ugyan számítógéppel generálták, de nincs bennük semmiféle múvészi ambíció, ahogy Sutherlandnél sem vetôdik fel a múvészeti alkotás igénye, pusztán a (bármilyen) képi tartalom számítógépes „interoperabilitása”; hogy a Spacewar! minimalista grafikája mint felhasználói felületté párolt „dizájn” sorolható akár éppen a „múvészethez” is, csak éppen annak az alkalmazott válfajához - a lényeg azonban itt nem az, mint egy találmány esetében, hogy minden kétséget kizáróan azonosítható legyen valakinek az „elsôsége”. 1963-ban már számítógépes múvészeti versenyt támogat a korabeli szaklap, a Computers and Automation. 1965-ben megnyílnak az első számítógépes múvészeti kiállítások (Stuttgartban és New Yorkban). A számítógépes múvészet nagykorúvá válásának és „befogadásának” emblematikus éve mégis 1968, amikor a Museum of Modern Art állandó gyújteménye részére megvásárolja az elsô számítógéppel készített rajzot: Charles Csuri Kolibri (Hummingbird) címú animációját.

Szerepe azóta sem évról évre fakuló históriai érdekesség, hanem valódi, meghatározó és múvészetileg is magasrendú hozzájárulás az új, digitális technikából kinövố kifejezési formák kereséséhez - tartós, idestova félszáz éves eleven jelenléttel, soha nem lankadó kísérletezókedvvel.

\footnotetext{
${ }^{5}$ Részletesen lásd Z. Karvalics László: Vasarely-vízió: a pécsi próféta és luminokinetikus képernyôje. In Fogpiszkúló a hálózaton. Írúsok az internetról. 2000, PRÍM Kiadó, 186-190.

"A Csurival készített „online interjúsorozatom” alkalmából 2007. február 10-én kelt válaszlevelében, részletesen lásd a lapszámban közölt teljes šövegben.

${ }^{7}$ What people can't realize is that in 1964 there was nobody with a background in art working with computers. I believe this was true worldwide. (Lasd uo. Z. K. L.)

${ }^{8}$ Részletesen lásd például: A brief history of computer graphics: Beginnings. The birth of electronic art. www.people.carleton.edu/ glabp/history.html
} 
Ahhoz képest, hogy alkotóként ugrik fejest a számítógépes múvészet medencéjébe, Csuri, az egyetemi polgár egyike a legelsóknek, akik teoretikus reflexióra is vállalkoznak. Elsố közleménye (Computer Graphics and the Arts) három évig vándorolt szerkesztôségrốl szerkesztôségre, míg végül a villamosmérnökök (!) szakfolyóirata, az International Journal for Electrical Engineering megjelentette." Az írás azonban soha nem vált Csurinál a gondolkodás és a kifejezés médiumává: nagyon ritkán érezte úgy, hogy meglátásainak nem képként, hanem megformált szövegként kell „testet” adnia. Legjellemzốbb múfaja a néhány oldalas, nagyon magas absztrakciós szintú, sứrú, erős humán múveltséganyaggal átitatott rövid esszé, amelyekben érzékenysége, bölcsessége, nyitottsága és korszerúsége újra és újra meglepi az olvasót. Csuri keveset, de aforisztikus tömörséggel írt. A lapunkban közölt írásai gondolkodói profiljának gyakorlatilag teljes keresztmetszetét adják.

"Talán még jellemzóbb, hogy amikor egyetemi kollégája, Matthew Baigell elküldi Csuri kéziratát a New York-i Artforumnak, Philip Leider a visszautasító szerkesztôi válaszlevélben egyenesen odáig megy, hogy kijelenti: „Nem tartom elképzelhetônek, hogy az Artforum hasábjain valaha is tematikus számként jelenhessen meg az elektronika vagy a számítógép a múvészetben." A levél fakszimiléjét közli az ćletmúkiállítás katalógusa (Charles A. Csuri: Beyond Boundaries. 1963, Present. Ed. by Janice M. Glowski. 2006, OSU, - College of the Arts, 41.) és olvasható Csuri weboldalán is. 